The Mighty Phalgu River Dries up

\title{
Vikram Kumar*
}

Assistant Professor, Gaya College of Engineering, Gaya, Bihar, India

*Corresponding Author: Vikram Kumar, Assistant Professor, Gaya College of Engineering, Gaya, Bihar, India.

Received: May 02, 2019; Published: August 01, 2019

DOI: 10.31080/ASAG.2019.03.0595

The Phalgu, a river that flows past Gaya, India in the Indian state of Bihar, is a sacred river for Hindus and Buddhists. The name Phalgu is believed to be a combination of phala (merit) and gau (wish-fulfilling cow). The etymology implies that the river manifests the highest power of piousness and merit. In ancient scriptures, it is called the Nairañjanā in Sanskrit. Hindu pilgrims from different parts of India gather on the banks of the river during monsoon in (September - October) for the 'Pitrapaksh Tarpan '. The pilgrims take a dip in the seasonal holy river 'Phalgu' during this season. The Phalgu is formed by the confluence, some 3 kilometres below Bodh Gaya, of the Lilajan (also called Niranjan or Nilanjan) and the Mohana, two large hill streams each of which is over 270 metres wide. The united stream flows on to the north past the town of Gaya, where it attains a breadth of over 820 metres.

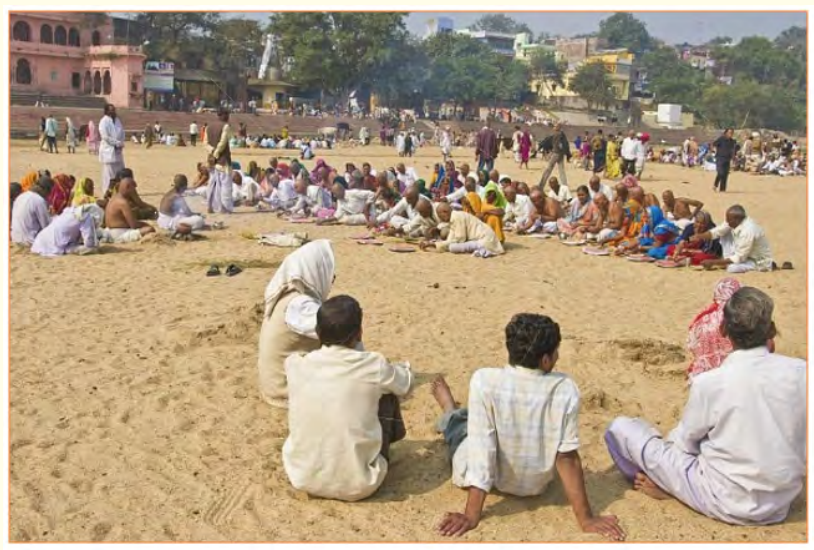

Figure 1: Groups of pilgrims wait to have their priest perform Hindu ceremonies on the dried-up bed of the Phalgu River.

Phalgu are losing water for a variety of conceivable reasons, say the investigators, including the installation of obstruction in the upstream by creating dams and the use of water for agriculture. Beside the said reason, over extraction of ground water in upstream and poor management of water resources are also responsible for tumbling the flow. But in many cases, the decrease in flow is because of climate change, which is fluctuating rainfall patterns and increasing evaporation because of higher temperatures. "Reduced run-off or drying of river" is increasing the pressure on the available freshwater resources in much of the world not only in Bihar and other part of the India, especially with more demand for water as population increases. Indus Basin and the Ganges-Brahmaputra Basin water levels falling by 4-6 mm/year. Everyone knows about Saraswati, which has gone underground. In UP, Gomti has gone dry in its upper catchment. The river has lost its tributaries in almost all the districts through which it flows. Behta has shunk to ponds. Bhainsi and Tareuna in Shahjahanpur have gone almost so dry that for $16 \mathrm{~km}$, no river is visible. Chhoha and Andhra Chhoha in Lakhimpur are almost dry as ground water level in nearby areas has fallen considerably. With a baseline water stress score of 4.15, India's Palar River placed 15th on WRI's list of the world's most water-stressed rivers. Nayyal is another river in TN that is endangered along with waterways of Chennai (Cooum and Adyar river).

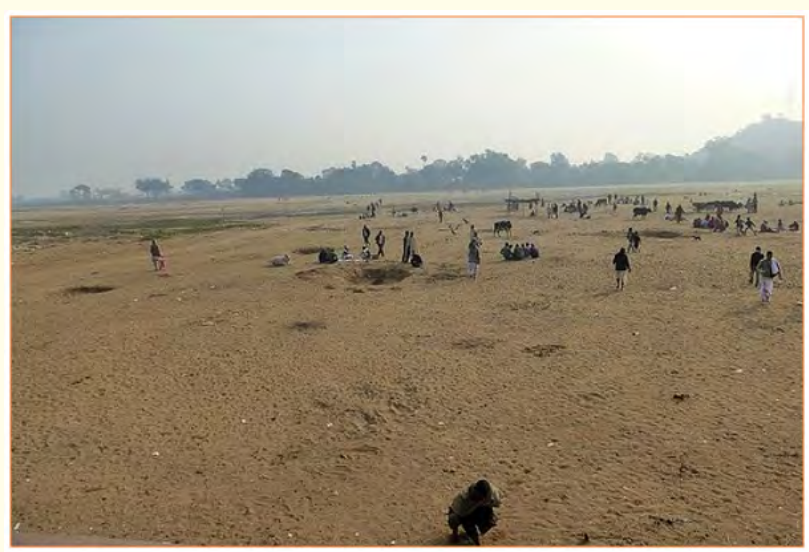

Figure 2: Phalgu with its extensive sand beds and dry river.

The India accounts for about $17 \%$ of the world's population but has only $4 \%$ of the world's fresh water 1,544 cubic metre per capita annual availability, India is already a water stressed country and rapidly moving towards becoming water scarce. The Freshwater in river being a vital resource, the downward trends are a great 
concern," said Aiguo Dai, a scientist at NCAR and lead author of the research. Phalgu water systems are also habitat for diverse fauna and flora which provide an important source of food and fiber that sustain incomes and livelihoods, particularly for rural communities in India. Experts predict that water availability will be one of the major challenges facing human society and that the lack of water may be a key factor limiting development. Thus, there is an ever increasing need and urgency for improved management of freshwater ecosystems with asking major questions such as:

- What are the key pressures on and drivers of reducing the river flow in Phalgu

- What are the most illustrative examples of these threats, and

- What recommendations or solutions can we pose to address these threats?

In conclusion, I can say that, there are potential to manage and govern the Phalgu water by adopting the strategies of: $\urcorner$ Jal Sanchay (water storage), Jal Sinchan (efficient water use) and Jan Sanrakshan (water conservation).

Volume 3 Issue 9 September 2019

(C) All rights are reserved by Vikram Kumar. 